づ族サ期家編論容

け福、に族者点易第示 が祉ビおにの整に一唆 なとスけよ野理みにに さとのるる々へえ、富 れい体自そ山のて家む てう系立の久積容家好 き概で的家也極易族著 た念あ遂族は的な福㟟 ひぬる。の行機述な取ざと禈あ とぐレ援にる能るは組る つつ周助つ多定何 にて知のい家が義か はは搳て家なづし 家、よ践の族さけと 族異う䈏れ家福的 のなにそ族祉てむう、 福るに性といけ、 祉定家援活はる。て

\section{野々山久也 編著}

\section{家族福祉の視点}

——多様化するライフスタイルを生きる——

(A 5 判 300 頁 $¥ 2,800$ ミネルヴァ書房 1992 年)

しとくえ家ポサ選いい注の等的をへ体山精二箪分機 たし、て族! ポ択。え自基第援援のと桂精 位野能

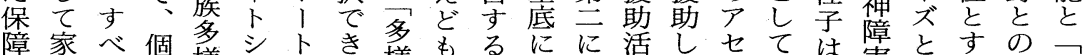

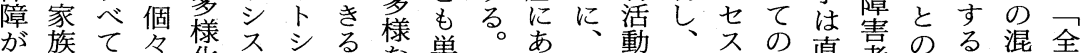

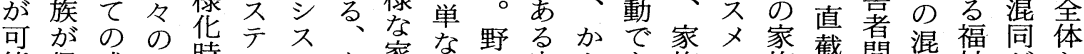
能保成家時么テあ家な野家よあ族ン族截問混祉がと に障員族代がムる族る山族うる。全卜”題同等市し なすがにの家しい形うはのに。体にを指かと市うて

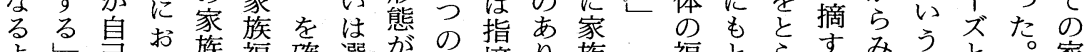

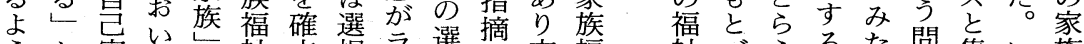
うか実てへ祉立択 ラ選方方福祉ゔえる。た問集い族 にた現てへですでイ択るそ祉追いて題団また 家ちで二の市るき視る対。のを求て集家族がをひを

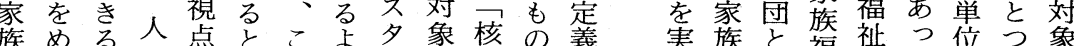
族める。点とここよ社つ位つ象

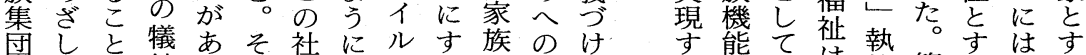
を、を牲るこ会社とぎ形視る年るのの第る個る 援そ集も。に的会しし態点电專強家”の五福人福 助う団な加はサ的てなと学そ阴化族全横章祉を祉

に章で会孤別ス四宅介移回福スは福テ家て把濭す お马追は立分当章に護動避祉を述祉イ族い握第目る

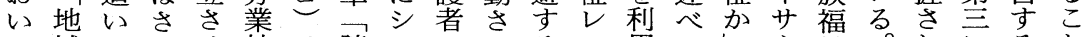
て域こ瓷んせ社は障

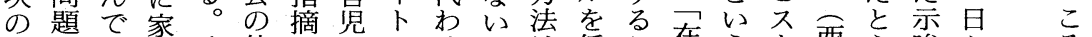

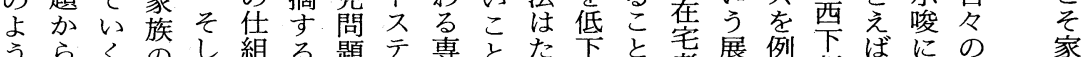

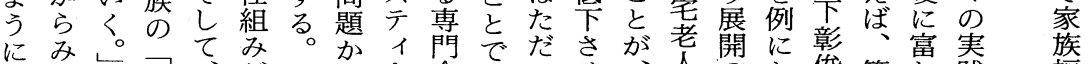

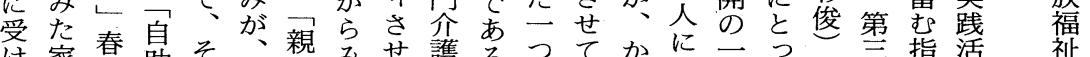
け家春助そ心親みせ護るつてかに二䄈 と族の早母旗たる年ししえ対端てに章摘動の

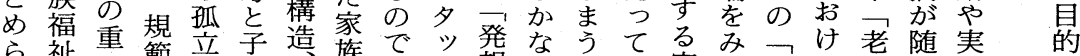

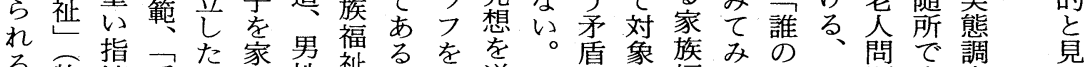
る。牧摘愛母族性祉る。を逆在し直老福よたの゙題光査見

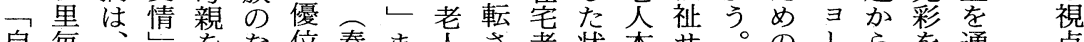
自毎、息な位春ま人さ老状本サ。の।らを通点

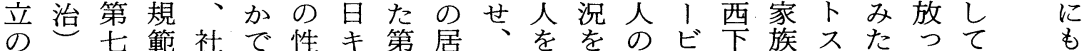


てど $\vdots る$ 祉複福う里る福て童でりの自プで集す軸 いの $\vdots$ 視政合祉に毎視祼、福あ、第次立、は団こで

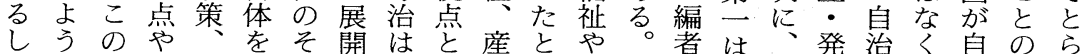
な三展社示れし先は業え老編と若達体、包方元 医属つ望会すにてに異福ば人者執家芉しに仲完がる 療人のを福分似い引な祉岡福の筆族気て支間結むの ・的概表祉分てる用ると村祉野者福にい文集的しで

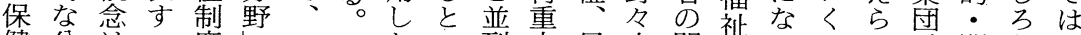
健分は、度し二家たい列夫母山間のつこれ閉必な 福野、論ので定家第う。すが子にに概たとな地鎖要く 祉を児理ああの族峷。るこ福よみ点がが域的な、 示童—方空重ら組にの依 司す福を方と!祉にか祉をと隹住つ要、織自で存 法も祉内全とビの扢し分医並、る位いな家立あの 福のや包体も不概い、野療ぶ家无置での族専立る。軸 祉と老しをに体念てたと福も族レづ述で集丣自るで

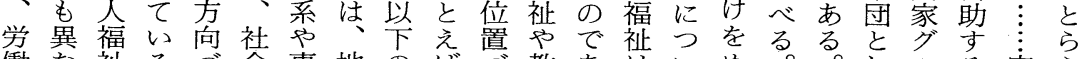

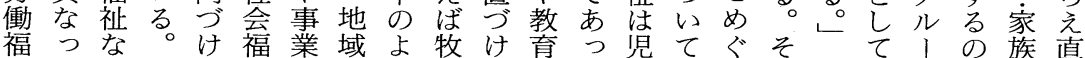

テ域れとにが族生パ童り疑福れおな者で合れビも祉 イ福な家論重命、品牧問祉るさ視のは的のス異な で祉け族じ要のとソ老里をを。点共な領福全など はがれ福るで福生ナ人のも児第故は著い域祉体うの なコば祉こあ祉活ルそ見つ童云に当とだを分をてょ くミなのとるをの・し解。深に然いろ示野ネいう

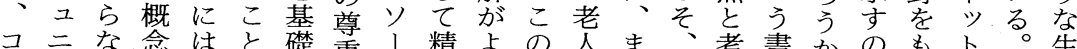

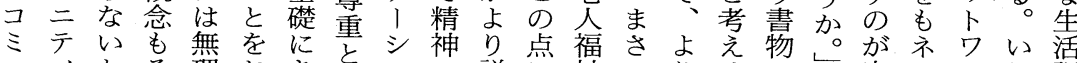

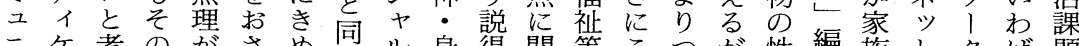
二ケ考のがさめ時ル身得関等こつが性編族トクば題 テアえ包あえ細時・体力し方のめ格者福りし別

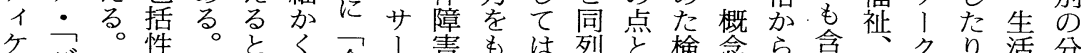

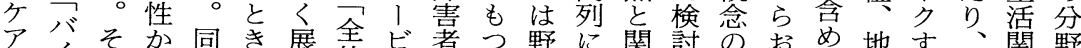

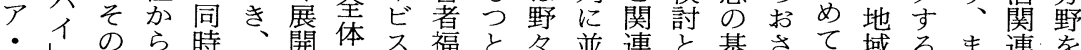

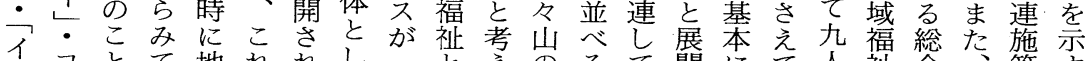

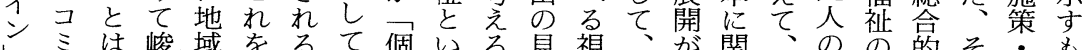
こミは峻域をるて個いる見視、が関、のの的そ・も - ב 別福同この の つ解点家望わ多研概、的少の コ二地さ祉列と家のた児よに族まる椂究念統ぞ、と

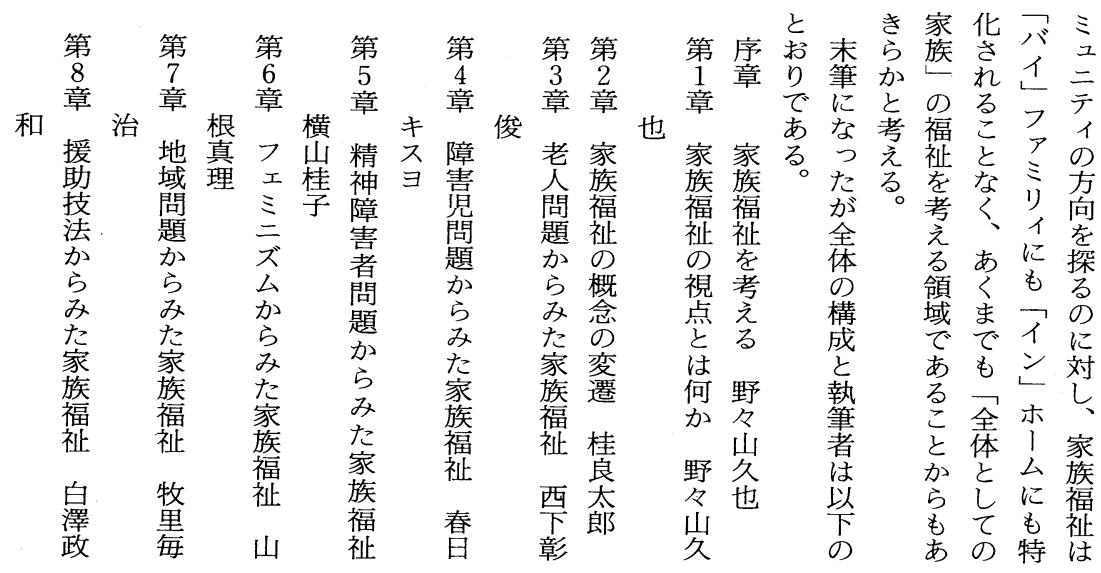




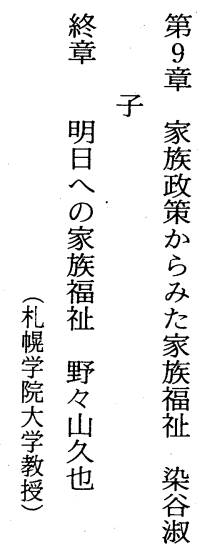

の理のら本し知がの 要㐌果究畫時好るる 理展研を著に㢊のうコ 論開究し者㥕心だかミ を動主き住基うそ究 め向軸た二異基加の者 ゔを定なく。根は て紹し人のる研単底

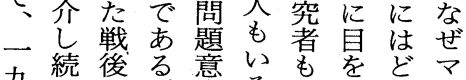
九情の。識るい引の 七て欧著をだるくょコ き米者もろ加社うミ 年たのはちう。も会なを 代。マ $、$ 続 し $し$ 現問 研 後こススけ加題究 半れココな吕なへ意す 以らミミがしいいの識る

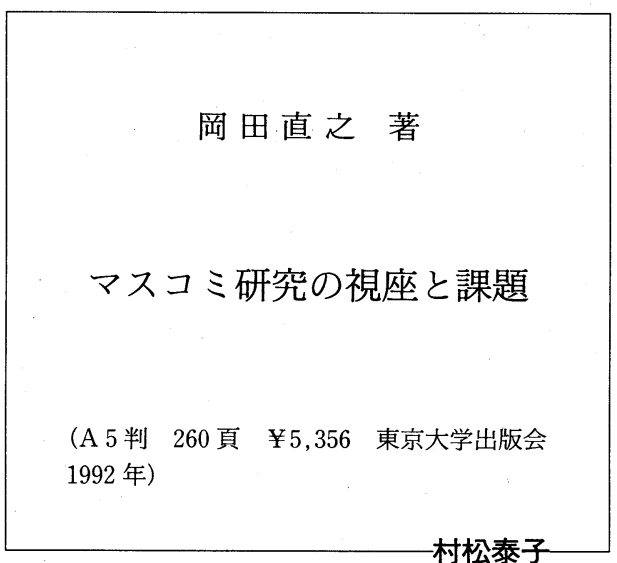

村松泰子

会中間書論でマーうう治価的の心こいめ意篇降 的間ヨ書を合二う。姿的値視役的と。ぐマつ識を ココンか含マコ $\bigcirc$ 。蓺文前座割主を著るスて䈐ほ ミミ構れむるミの脈提をと題鮮者社コくそんほ ユュ造た基コ研論貫を・息機は明は会ミる。のだ 二 二等本ミ究文加析背賞能民に层的理。根本ン ケケで第的のの文

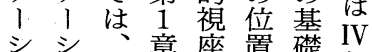
シ シ 対章座 置 礎 IV ンン人現扱 け視に の・コ代うを座 構 構 マミ社てめ坐成 造スュ会いぐはさ どコニのるるるれ 社ミケココ諸全て

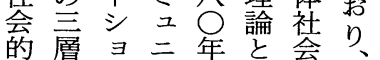

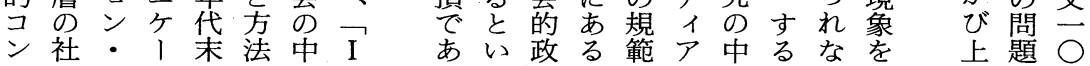
れ出後しの主し民歴論底書

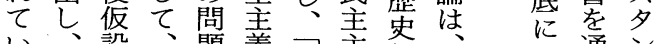
い設、題義そ奎的流通ン るそのあスで会も義条メ゙流読上

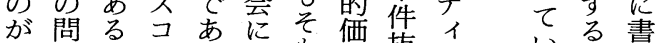

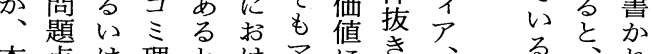

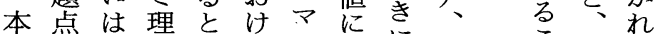
書を理論する不コにマるて

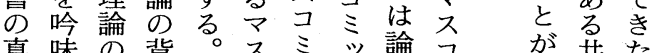
真味の背。スミッ論コ吱共た 骨夺社後そメ研トじミ浮通論 頂る会にの究しら現加の文 